ORIGINAL ARTICLE

PRACA ORYGINALNA

\title{
PREVALENCE OF THE GENERALIZED PERIODONTITIS IN PATIENTS WITH DIFFERENT GROUPS BLOOD IN DEPENDING ON AGE AND PERIODONTAL BIOTYPE
}

DOI: 10.36740/WLek202001123

\author{
Yurii L. Bandrivsky ${ }^{1}$, Orysia 0. Bandrivska², Roksolana Yu. Shkrebnyuk³ ${ }^{3}$, Volodimira T. Dyryk ${ }^{3}$ \\ 'DEPARTMENT OF CHILD DENTISTRY, I. HORBACHEVSKY TERNOPIL NATIONAL MEDICAL UNIVERSITY, TERNOPIL, UKRAINE \\ 2DEPARTMENT OF ORTHOPEDIC DENTISTRY, I. HORBACHEVSKY TERNOPIL NATIONAL MEDICAL UNIVERSITY, TERNOPIL, UKRAINE \\ ${ }^{3}$ DEPARTMENT OF THERAPEUTIC DENTISTRY FPGE, DANYLO HALYTSKY LVIV NATIONAL MEDICAL UNIVERSITY, LVIV, UKRAINE
}

\begin{abstract}
The aim of the study was to investigate the prevalence of generalized periodontitis depending on age and biotype of periodontium.

Materials and methods: We examined 855 males aged 20-55 years, who were divided into 2 groups: the main group - 570 surveyed with a generalized periodontitis, the comparison group - 285 dental healthy individuals.The diagnosis of generalized periodontitis was established by the classification Danilevsky M.F. (1994) and refined by using paraclinical indices. The periodontal biotype was determined using Hu-Friedy Colourvue Biotype Probe.

Results: As a result of the conducted researches was establish, in the carriers of blood group 0 (I) and A (II), developed forms of generalized periodontitis were found, on average, 2.7 times more often than the initial forms of the disease. Instead, at the representatives of $B$ (III) and AB (IV) groups blood the frequency of initial GP - I degree was on average, 1.2 times greater than the prevalence of developed forms of generalized periodontitis. Also as a result of our researches, we found that the cluster $\mathrm{A} 1$ had $39.30 \%$ patients, cluster $A 2$ was found at $28,77 \%$, and cluster $B-31.93 \%$ of the total number of patients with generalized periodontitis.

Conclusions: As a result of our research, it was found that in the carriers of the blood group 0 (I) and A (II), more advanced forms of generalized periodontitis were observed, which was confirmed by the presence of the biotype of the periodontal disease in the cluster A1 and A2.
\end{abstract}

KEY WORDS: generalized periodontitis, blood group, periodontal biotype

Wiad Lek. 2020;73(1):119-122

\section{INTRODUCTION}

Epidemiological studies show a steadily high prevalence of periodontal disease already at young people $[1,2]$. According to most authors, the most common form of periodontal pathology in adolescents and children have gingivitis $[3,4]$. But with age, single frequency more severe lesions (periodontitis) and the number of teeth removed significantly increased [5]. When exploring out numerous papers on the leading role of local factors in the development of diseases of periodontal tissues, it can be noted their contradiction and the increasing need to use to explain some of the provisions role of endogenous factors [6]. In the study of pathogenetic mechanisms of development of inflammatory diseases of the periodontal, many hypotheses were formed, the main ones of which it is possible to consider immunological, neurogenic, vascular $[7,8,9]$.

One drawback in the study of periodontal disease is the fact that many researchers trying to explain the apear of the pathological process pointing out only one reason $[10,11]$. However, in solving the problems of pathogenesis and diagnosis of periodontal diseases, it is necessary to agree with the point of view on the need for a systematic approach, the content of which is to ensure that each component of the body's biosystem is not interpreted as an independent formation [12].

\section{THE AIM}

Investigate prevalence generalized periodontitis in patients with different group affiliation blood depending on age and biotype of periodontium.

\section{MATERIALS AND METHODS}

The study was conducted in clinics in the city of Ternopil and Ternopil regional blood transfusion station in 2014 2016 years. We examined 855 males aged $20-55$ years, who were divided into 2 groups. The main group consisted of 570 surveyed with a generalized periodontitis I- III severity who applied for periodontal help to our clinic. In the comparison group included 285 dental healthy individuals. Patients in both groups of the study were somatically healthy, which was confirmed by the absence of complaints, physical examination data and corroborated lack of non-communicable and infectious diseases, according to outpatients cards. The diagnosis of generalized periodontitis was established by the classification Danilevsky M.F. (1994) and refined by using paraclinical indices $[13,14]$. The periodontal biotype was determined using Hu-Friedy Colourvue Biotype Probe [15]. The obtained results were processed statistically using the software packages "Statgraphics" and "Statistica 6.0". 
Table 1. Prevalence of generalized periodontitis in patients with a different blood group affiliation depending on age.

\begin{tabular}{|c|c|c|c|c|c|c|c|c|c|c|c|}
\hline \multirow{3}{*}{$\begin{array}{l}\text { Blood } \\
\text { groups }\end{array}$} & \multirow{3}{*}{$\begin{array}{c}\text { Degree } \\
\text { GP }\end{array}$} & \multicolumn{10}{|c|}{ Age groups } \\
\hline & & \multicolumn{2}{|r|}{$20-24$} & \multicolumn{2}{|r|}{$25-29$} & \multicolumn{2}{|r|}{$30-34$} & \multicolumn{2}{|r|}{$35-44$} & \multicolumn{2}{|r|}{$45-55$} \\
\hline & & abs. & $\%$ & abs. & $\%$ & abs. & $\%$ & abs. & $\%$ & abs. & $\%$ \\
\hline \multirow{3}{*}{$\mathrm{O}(\mathrm{I})$} & GPI & 21 & $43,75 \pm 7,16$ & 15 & $31,25 \pm 6,69$ & 12 & $25,00 \pm 6,25$ & - & - & - & - \\
\hline & GP II & 4 & $6,35 \pm 3,07$ & 7 & $11,11 \pm 3,96$ & 13 & $20,63 \pm 5,09^{\circ}$ & 18 & $28,58 \pm 5,69^{\circ}$, & 21 & $33,33 \pm 5,93^{\circ 0}, * *$ \\
\hline & GP III & - & - & 4 & $5,47 \pm 2,66$ & 11 & $15,07 \pm 4,18$ & 26 & $35,62 \pm 5,60 * *$ & 32 & $43,84 \pm 5,80^{* *}$ \\
\hline \multirow{3}{*}{ A (II) } & GPI & 18 & $37,50 \pm 6,98$ & 17 & $35,42 \pm 6,90$ & 13 & $27,08 \pm 6,41$ & - & - & - & - \\
\hline & GP II & 3 & $4,62 \pm 2,60$ & 9 & $13,85 \pm 4,28$ & 15 & $23,07 \pm 5,22^{\circ \circ}$ & 16 & $24,61 \pm 5,34^{\circ \circ}$ & 22 & $33,85 \pm 5,87^{\circ \circ}, *$ \\
\hline & GP III & - & - & 10 & $17,86 \pm 5,11^{\mathbf{\Delta}}$ & 13 & $23,21 \pm 5,64$ & 16 & $28,58 \pm 6,04$ & 17 & $30,35 \pm 6,14$ \\
\hline \multirow{3}{*}{ B (III) } & GPI & 25 & $38,46 \pm 6,03$ & 15 & $23,07 \pm 5,22$ & 16 & $24,62 \pm 5,34$ & 9 & $13,85 \pm 4,28^{\circ \circ}$ & - & - \\
\hline & GP II & - & - & 5 & $15,63 \pm 6,41$ & 6 & $18,75 \pm 6,89$ & 14 & $43,75 \pm 8,76$ & 7 & $21,88 \pm 7,30^{*}$ \\
\hline & GP III & - & - & - & - & 4 & $17,39 \pm 7,90$ & 13 & $56,52 \pm 10,33$ & 6 & $26,09 \pm 9,15=$ \\
\hline \multirow{3}{*}{$A B(I V)$} & GPI & 23 & $43,40 \pm 6,80$ & 11 & $20,75 \pm 5,70^{\circ}$ & 10 & $18,87 \pm 5,37^{\circ}$ & 9 & $16,98 \pm 5,15^{\circ \circ}$ & - & - \\
\hline & GP II & - & - & 4 & $14,28 \pm 6,61$ & 6 & $21,43 \pm 7,75$ & 10 & $35,71 \pm 9,08$ & 8 & $28,58 \pm 2,53$ \\
\hline & GP III & - & - & - & - & 6 & $37,50 \pm 12,10$ & 6 & $37,50 \pm 12,10$ & 4 & $25,00 \pm 10,82$ \\
\hline
\end{tabular}

Notes: $1 .{ }^{\circ} \mathrm{p}<0.05 ;{ }^{\circ 0} \mathrm{p}<0.01-$ a reliable difference in values with respect to data in patients 20 -24 years 0 ld.

2. ${ }^{*} \mathrm{p} 1<0,05 ;{ }^{* *} \mathrm{p} 1<0,01-$ a reliable difference in values with respect to data in patients $25-29$ years old.

3. $\square \mathrm{p} 2<0,01-$ a reliable difference in values with respect to data in patients $30-34$ years old.

4. $\Delta$ p3 $<0,05-$ a reliable difference in values with respect to data in patients with 0 (I) blood group.

\section{RESULTS AND DISCUSSION}

According to the clinical examination in the 570 patients with generalized periodontitis (GP) with a different blood group affiliation, found that regardless of blood type, was reduced prevalence of early forms of GP (table 1). In patients with a blood group $\mathrm{O}$ (I) prevalence initial - I severity degree decreased from $43,75 \pm 7,16 \%$ of $20-24$ aged till to $25,00 \pm 6,25 \%$ in patients aged $30-34$ years was examined, $\mathrm{p}>0,05, \mathrm{p}_{1}>0,05$. and in carriers A(II) blood - from 37,50 $\pm 6,98 \%$ in the younger age group to $27,08 \pm 6,41 \%$ in the age range $30-34, \mathrm{p}>0.05 \mathrm{p}_{1}>0.05, \mathrm{p}_{3}>0.05$. The attention was attracted that in people with $\mathrm{O}$ (I) and $\mathrm{A}$ (II) blood groups aged 35-55 years initial generalized periodontitis - I severity degree are not diagnosed. In the patients with a blood group B(III) incidence of early forms of GP in the 20-24 year amounted to $38,46 \pm 6,03 \%, \mathrm{p}_{3}>0.05$ and significantly decreased to $13,85 \pm 4,28 \%, \mathrm{p}<0,01, \mathrm{p}_{3}>0,05$, in the patients aged 35-44. In individuals with blood group $\mathrm{AB}(\mathrm{IV})$ prevalence GP initial - I severity degree in age intervals 20-24 years was significantly higher for the data in all age groups ( $\left.\mathrm{p}, \mathrm{p}_{1}<0.05 ; \mathrm{p} 2<0.01\right)$. It should be noted that the carriers blood group $\mathrm{B}$ (III) and $\mathrm{AB}$ (IV) aged 45-55 years the original form of generalized periodontitis not diagnosed.

The prevalence of GP II degree of severity with age increased in all study groups, regardless of the blood group's [16,17].

Thus, in patients with $\mathrm{O}(\mathrm{I})$ blood group, aged 20-24 years, prevalence GP II degree severity was 6,35 $\pm 3,07 \%$ and gradually increasing, reached $20,63 \pm 5,09 \%$ at age $30-34$ years $\mathrm{p}<0,05$ and $28,58 \pm 5,69 \%$ at the $35-44$ aged patients $\mathrm{p}, \mathrm{p}_{1}<0,05$. In this case, the maximum incidence of GP II degree severity was found in the group examine aged 45-55 years $-33,85 \pm 5,87 \%, \mathrm{p}_{1} \mathrm{p}_{1}<0.01$. In patients with A(II) blood group prevalence GP II degree severity increased from $4,62 \pm 2,60 \%$ of $20-24$ year examined to $23,07 \pm 5,22 \%$ in the age range $30-34$ years, $p<0,01$ and up to $24,61 \pm 5,34 \%$ of aged group $35-44, \mathrm{p}<0,01$. The highest prevalence of the GP II degree severity was installed in the 45-55 aged group of patients $-33,85 \pm 5,87 \%, \mathrm{p}<0,01$, $\mathrm{p}_{1}<0,05[18,19,20]$.

Attracted attention that the carriers $\mathrm{B}(\mathrm{III})$ and $\mathrm{AB}(\mathrm{IV})$ blood group with GP II degree severity in the younger age group (20-24 years) was not detected. At the age of 25-29 years, the prevalence of GP II degree severity was $15,63 \pm 6,41 \%$ of representatives blood group B (III) and $14,28 \pm 6,61 \%$ in patients with blood group $\mathrm{AB}(\mathrm{IV})$. The maximum spread GP II degree severity was in carriers $\mathrm{B}(\mathrm{III})$ and $\mathrm{AB}(\mathrm{IV})$ blood group was the age group 35-44 years $-43,75 \pm 8,76 \%$ and $35,71 \pm 9,08 \%$ respectively $p_{1}>$ 0,05 . In the $45-55$ year old patient, representatives of $B$ (III) and $\mathrm{AB}(\mathrm{IV})$ blood groups, the prevalence of GP II degree severity decreased and amounted to $21,88 \pm 7,30 \%, \mathrm{p}_{1}<0,05$ and 28,58 $\pm 853 \%$, respectively.

Prevalence GP III degree severity in the study group was of the same trend that characterized its increase depending on age. However, this nosological unit not diagnosed at the age of 20-24 years in carriers of $\mathrm{O}$ (I) and $\mathrm{A}$ (II) blood groups and the representatives of $\mathrm{B}$ (III) and $\mathrm{AB}(\mathrm{IV})$ blood groups in the age range 20-29 years.

In people with $\mathrm{O}$ (I) blood group the frequency of detection of GP of the III degree of severity increased from $5.47 \pm 2.66 \%$ at the age of $25-29$ years to $35.62 \pm 5.60 \%$ in $35-44$ year-olds, $\mathrm{p}_{2}<0,01$, reaching the maximum values in the age group $45-55$ years $-43,84 \pm 5,80 \%, \mathrm{p}_{1}<0,01$. 
Table 2. Variations of periodontal biotypes depending from blood groups in patients with generalized periodontitis

\begin{tabular}{|c|c|c|c|c|c|c|c|c|}
\hline \multirow{3}{*}{ Periodontal biotype } & \multicolumn{8}{|c|}{ Generalized periodontitis $(n=570)$} \\
\hline & \multicolumn{2}{|c|}{$\begin{array}{c}O(I) \\
(n=184)\end{array}$} & \multicolumn{2}{|c|}{$\begin{array}{c}A \text { (II) } \\
(n=169)\end{array}$} & \multicolumn{2}{|c|}{$\begin{array}{c}\text { B (III) } \\
(n=120)\end{array}$} & \multicolumn{2}{|c|}{$\begin{array}{l}A B(I V) \\
(n=97)\end{array}$} \\
\hline & abs. & $\%$ & abs. & $\%$ & abs. & $\%$ & abs. & $\%$ \\
\hline $\begin{array}{c}\text { Cluster } \\
\text { A1-Thin S }\end{array}$ & 81 & $\begin{array}{c}44,02 \pm \\
\pm 3,64\end{array}$ & 78 & $\begin{array}{c}46,15 \pm \\
\pm 3,83\end{array}$ & 32 & $\begin{array}{l}26,67 \pm \\
\pm 4,04^{\circ}\end{array}$ & 24 & $\begin{array}{l}24,74 \pm \\
\pm 4,38^{\circ}\end{array}$ \\
\hline $\begin{array}{c}\text { Cluster } \\
\text { A2-TS }\end{array}$ & 53 & $\begin{array}{c}28,80 \pm \\
\pm 3,38\end{array}$ & 47 & $\begin{array}{c}27,81 \pm \\
\pm 3,45 \\
\end{array}$ & 40 & $\begin{array}{c}33,33 \pm \\
\pm 4,30\end{array}$ & 33 & $\begin{array}{c}34,02 \pm \\
\pm 4,81 \\
\end{array}$ \\
\hline $\begin{array}{c}\text { Cluster } \\
\text { B-TF }\end{array}$ & 50 & $\begin{array}{c}27,18 \pm \\
\pm 3,28\end{array}$ & 44 & $\begin{array}{c}26,04 \pm \\
\pm 3,38\end{array}$ & 48 & $\begin{array}{l}40,00 \pm \\
\pm 4,47^{\circ 0}\end{array}$ & 40 & $\begin{array}{l}41,24 \pm \\
\pm 4,99^{\circ 0}\end{array}$ \\
\hline
\end{tabular}

Notes: ${ }^{\circ} \mathrm{p}<0,01$;

${ }^{\circ} \mathrm{p}<0,05$ - reliably difference the data values in patients with GP with blood group 0 (I).

Attention was attracted to the fact that in the carriers group blood A (II) the prevalence of the GP of the III degree of severity increased with age: from $17,86 \pm 5,11 \%$ in the examine $25-29$ years old to $30,35 \pm 6,14 \%$ in people aged 45-55 years, in the absence of statistical reliability in all age groups of the study $\left(\mathrm{p}_{1}, \mathrm{p}_{2}>0.05\right)$. In the representatives of $\mathrm{B}$ (III) and AB (IV), the blood groups of the GP of the III degree of gravity began to appear at the age of 30-34 years: in $17,39 \pm 7,90 \%$ and $37,50 \pm 12,10 \%$, respectively. In the age group of 35-44 years old in patients with B (III), the blood group noted the maximum frequency of detection of this nosological unit: $56.52 \pm 10.33 \%$ of the subjects with a decrease to $26.09 \pm 9.15 \%$ examined at the age of $45-55$ years old, $\mathrm{p}_{2}<0.05$. Attention was attracted to the fact that in the blood carriers AV (IV) the prevalence of the GP of the III degree of severity at the age of 35-44 years was equal to the data of 30-34 year-old inspected $(37,50 \pm 12,10 \%$, $\left.\mathrm{p}_{2}>0,05\right)$ and decreased to $25.00 \pm 10.82 \%$ of the patients in the age group 45-50 years.

Thus, as a result of the conducted researches, a significant dominance of the initial forms of generalized periodontitis has been established in young people with the prevalence of its developed forms in older age groups, regardless of the group membership of the blood. At the same time, in the carriers of blood group O (I) and A (II) blood groups, developed forms of generalized periodontitis were found, on average, 2.7 times more often $(p<0,05)$ than the initial forms of the disease. Instead, at the representatives of $B$ (III) and $\mathrm{AB}$ (IV) blood groups the frequency of initial GP - I degree was, on average, 1.2 times greater than the prevalence of developed forms of generalized periodontitis, $\mathrm{p}>0.05$.

According to literature data variant of the anatomy of the periodontal tissues can, with a high degree of probability, can predict option development and severity of periodontal pathological processes. Therefore, the first step was to determine the biotype of periodont in patients with GP with different blood groups.

As a result of our research, we established that the cluster A1 (thin - scalloped gingival biotype, ThinS) had 39.30\% (224 patients), cluster A2 (thick - scalloped gingival biotype, TS) were found in $28.77 \%$ (164 inspected) and cluster B (thick - flat gingival biotype,TF) - 31.93\% (182 people) of the total number of patients with generalized periodontitis (570 patients).

According to table 2, it was found that in patients with a GP of the $\mathrm{O}$ (I) blood group the cluster A1-Thin S was found in $44.02 \pm 3.64 \%$ of the examined ones, which was comparable with the data in patients with GP, carriers A (II) blood groups $(46,15 \pm 3,83 \%, p>0,05)$. At the same time, in patients with generalized periodontitis with $\mathrm{B}$ (III) and $\mathrm{AB}$ (IV) in the blood group, the periodontal A1 biotype was found reliably less ( $26.67 \pm 4.04 \%$ and $24.74 \pm 4.38 \%, p<0.01$, respectively). The average periodontal biotype (A2-TS) in the $\mathrm{O}$ (I) blood group was detected in $28,80 \pm 3,38 \%$ of the examined ones, which did not differ from the data of the remaining groups of patients examined, patients with GP ( $p>0,05)$. At the same time, it was noted that in the patients with generalized periodontitis with $\mathrm{B}$ (III) and $\mathrm{AB}$ (IV) blood group, the cluster B-TF was determined reliably more often $(40,00 \pm 4,47 \%$ and $41,24 \pm$ $4,99 \%, \mathrm{p}<0.05$, respectively) than in patients with GP from $\mathrm{O}$ (I) and A (II) in blood groups (27,18 $\pm 3,28 \%$ and $26,04 \pm$ $3,38 \%$, respectively).

Thus, as a result of the conducted researches, a significant dominance of the initial forms of generalized periodontitis has been established in young people with the prevalence of its developed forms in older age groups, regardless of the group membership of the blood. But attention was attracted that in carriers O (I) and A (II) blood groups, the prevalence of GP initial - I severity was significantly lower, and the frequency of detection of II-III severity GP was higher relative to the corresponding data in patients with B (III) and AB ( IV) blood groups [20,21,22].

The obtained data about periodontal biotypes allow us to conclude that the carriers of O (I) and A (II) blood groups, suffering for GP was observed morphological inclination to the emergence and intensification of inflammatory and dystrophic changes in periodontium, due to the prevalence of gingiva biotypes of the cluster $\mathrm{A} 1$ and $\mathrm{A} 2$. At the same time, the carriers of $\mathrm{B}$ (III) and $\mathrm{AB}$ (IV) blood groups, with $\mathrm{GP}$, determined the opposite tendency according to the cluster B-TF wich have a protective factor of predisposition to the inflammatory diseases of periodontal tissues [23,24]. 


\section{CONCLUSIONS}

This study clarifies and complements the data on the incidence of generalized lesions of periodontal tissues in people of all ages, depending on the blood group by a system $\mathrm{AB} 0$. Monitoring of the cluster affiliation of periodontal biotype can serve as an early marker for the diagnosis of periodontal tissue diseases, will allow for the correction and optimization of therapeutic measures for this contingent of patients.

\section{REFERENCES}

1. Srivastava N, Nayak PA, Rana S. Point of care - a novel ap-proach to periodontal diagnosis - a review. J Clin Diagn Res. 2017;11(8): ZE01ZE06.

2. Bandrivsky Y, Bandrivska 0, Gnid R, Minko L, Shevchuk M. Indicators of markers of bone metabolism in patients with generalized periodontitis depending on blood group. Arch Balk Med Union 2019;54(1):72-77. doi. org/10.31688/ABMU.2019.54.1.10

3. Iryna S. Dankevych-Kharchyshyn et al. Periodontal diseases and atherosclerosis (literature reviewwiad) Wiad Lek 2019;72(3):462-465

4. Daniels GL, Anstee DJ, Carton JP, et al. Blood groups classification. Vox Sang. 2017; 69(4): 265-279.

5. Stahl SS. Host resistance and periodontal diseases. J Dent Res. 2010;49(2):248-255.

6. Offenbacher S. Periodontal diseases pathogenesis. Amer Periodontol. 2013;1: 821-878.

7. Clarke, C.A. Blood group and disease. Progress in medical genetics. 2012;1:4-8.

8. Greabu M, Totan A, Miricescu D, Radulescu R, Virlan J, Calenic B. Hydrogen sulfide, oxidative stress and periodon-tal diseases: a concise review. Antioxidants. 2016;5(1):3.

9. Landsteiner K., Witt D. Observation on the human blood groups. J. immunol. 2013;11:221-247.

10. Matu N.K., Stephen L., Lalloo R. Prevalence and severity of periodontal disease: type 2 diabeticsversus non-diabetes SADJ 2016;2:66-68

11. Schenkel-Bruner, H. Human blood groups: Chemical and biochemical basis of antigen specificity, New York, 2000;1.2:30-293.

12. Tomasi C., J.L. Wennstrum Full-mouth treatment vs. the conventional staged approach for periodontal infection control. Periodontology, 2009:51:45-62.

13. Danilevskiy N. F. Borisenko A. V. Zabolevaniya parodonta. Kyiv, Medytsyna. 2014; 461.

14. Borysenko AV. Therapeutic stomatology. Kyiv, Medytsyna, 2015; 2:409.

15. Van Dyke, T.E. Inflammation and periodontal diseases: a reappraisal Text. J. Periodontol. 2015;8:1501-2.

16. Petersen P. E. The global burden of oral diseases and risk to oral health. Bull. World Health Organ. 2015;83(9):661-669.

17. Bandrivska NN, Bandrivsky YL. Clinical morphology symptomatics of inflammatory parodontal diseases. Ukrainskyi medychnyi almanakh. 2009;(5):19-21 (in Ukrainian).

18. Shiau HJ, Reynolds MA. Sex differences in destructive periodontal disease: a systematic review. J Periodontol. 2013;81(10):1379-1389.
19. Fourel J. Periodontosis: a periodontal syndrome. J Periodontol. 2012;43:240-255.

20. Haffajee AD, Socransky SS. Microbial etiological agents of destructive periodontal diseases. Periodontology. 2016; 5:78-111.

21. Bennet E, Steffensen R, Clausen H, et al. Genomic cloning of the human histo-blood group ABO locus. Biochem Biophys Res Commun. 2014; 206:318-325.

22. Isacov I, LevcoS. Preoperative assessment of patients with inflammatory processes in the maxillo-facial region: a minireview. Arch Balk Med Union. 2018;53(2): 275-280.

23. Yamamoto, F. Molecular genetic of the ABO histo-blood group system. Vox Sang. 2015;69:1-7.

24. Neil DA, Reid ME. The Rh blood group system: a review. Blood. 2011;15:375-387.

The work is a fragment of scientific research work of the Department of Pediatric Dentistry at the «I. Horbachevsky Ternopil National Medical University of the Public Health of Ukraine» "Study of metabolic homeostasis of the body in diseases of the oral cavity in people of different ages and optimization of their treatment and prevention" (state registration number 0116U004146).

\section{ORCID and contributionship:}

Yurii Bandrivsky - 0000-0002-4103-3664 ${ }^{B, C, D}$

Orysia Bandrivska - 0000-0002-3274-1781 ${ }^{F}$

Roksolana Shkrebnyuk - 0000-0002-3440-1836 ${ }^{E}$

Volodimira Dyryk - 0000-0002-6383-8172 ${ }^{\mathrm{A}}$

\section{Conflict of interest:}

The Authors declare no conflict of interest

\section{CORRESPONDING AUTHOR Yurii Bandrivsky \\ Dept. of Child Dentistry, \\ I. Horbachevsky Ternopil National Medical University \\ Chekhova 7, Ternopil, 46001, Ukraine \\ tel: +380973047399 \\ e-mail: bandrivsky.83@gmail.com}

Received: 26.04 .2019

Accepted: 20.11.2019

A - Work concept and design, B - Data collection and analysis, C - Responsibility for statistical analysis, $\mathbf{D}$-Writing the article, $\mathbf{E}$-Critical review, $\mathbf{F}$ - Final approval of the article 